Copyright (C) 2017 by Academic Publishing House Researcher

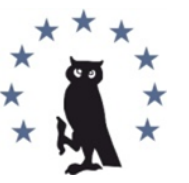

Published in the Russian Federation

European Researcher. Series A

Has been issued since 2010.

ISSN 2219-8229

E-ISSN 2224-0136

2017, 8(4): 297-312

DOI: 10.13187/er.2017.4.297

www.erjournal.ru

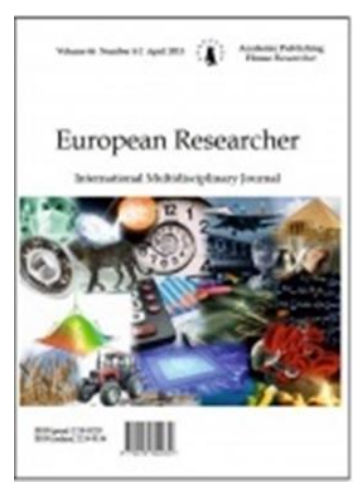

UDC 37

\title{
Hermeneutic Analysis of Soviet Films of the "Stagnation" Era (1969-1984) on the Student Theme
}

\author{
Galina Mikhaleva ${ }^{a}$, * \\ a Rostov State University of Economics, Russian Federation
}

\begin{abstract}
The article presents the results of the hermeneutic analysis of soviet films of the "stagnation" period (1969-1984) on the student theme. It compares the media texts to the cultural and historic tradition and reality of the "stagnation" era. The research objective was to analyze and characterize the cultural and historical contexts, to define the role and value of the university topic in the mirror of the Soviet cinema in terms of social studies, culture studies, film studies, anthropology, gender studies and media education. The author of the article concludes that the soviet cinematography of the "stagnation" epoch officially supporting the communist ideology: 1) referred to eternal topics in arts; 2) created mainly politically and ideologically neutral media texts focusing on critical reflection on reality, acute social conflicts, moral and patriotic education of youth, overall youth culture promotion; 3) reflected both positive aspects, achievements of the soviet state in the stagnation period, and negative sides of sociopolitical and cultural life of soviet people; 4) continued to use stereotyped role and gender media text character profiles; 5) broadened the scope of problems, narrative and genre range of media texts about university and students; 6) more realistically presented media images of university teachers and students in comparison to the cinematograph of the "thaw" period; 7) diversified the social typology of university students' and teachers' media images; 8) used a variety of artistic devices for describing characters and reality; 9) dynamized the dramatic and psychological effects in creating media texts personages, their characters and fates.
\end{abstract}

Keywords: hermeneutic analysis, media text, film, characters, media literacy, USSR, stagnationera, Soviet cinematography, university, students, teachers.

\section{1. Введение}

В данном исследовании приводятся результаты герменевтического анализа советских игровых фильмов эпохи «застоя» (1969-1984) на студенческую тему путем сопоставления данных медиатекстов с культурно-исторической традицией и действительностью эпохи, в которой они создавались.

Советский кинематограф эпохи «застоя» в литературе часто называют «застойным» или «кинематографом истощения», при этом «истощение здесь относится не только к кино

\footnotetext{
${ }^{*}$ Corresponding author

E-mail addresses: gmikhaleva@list.ru (G. Mikhaleva)
} 
как медиуму, но и к социальной реальности, в которой оно существует и которую репрезентирует» (Щербенок, 2013). Но утверждать, что все наследие кинематографа данного периода переживало исключительно стагнацию, на наш взгляд, было бы совершенно неправильно: «застойной» была система киноуправления и кинопроизводства, что самым прямым образом сказалось на облике значительной части кинорепертуара, нацеленной на пропаганду «достижений развитого социализма». Но параллельно развивалась и мощная «антизастойная» тенденция, противостоявшая официальным идеологическим и эстетическим установкам. Многочисленные фильмы, созданные в русле этой тенденции, обогатили наш экран бесспорными художественными достижениями и способствовали духовному развитию общества» (Власов, 1997: 4).

Идеологически «неангажированные» кинофильмы 1970 - начала 1980-х гг. отражали преимущественно кризисные социальные явления в политической, социальной, и культурной сферах советской жизни, а также постепенные изменения в общественном сознании и восприятии окружающей действительности того времени: «в самоощущении советского человека появились социальная инертность, недоверие к официальной идеологии - ко всему тому, что связывалось с понятием «развитой социализм». В общественном самочувствии жило предощущение катастрофы как в экономическом фундаменте, так и в идейно-духовной «надстройке». Между тем, партийно-государственный аппарат пытается удержать систему от предчувствуемого распада, реанимировать дряхлеющую идеологию, что оборачивается новым давлением на духовную сферу жизни, в том числе и на «важнейшее из всех искусств» кино. Однако, несмотря на ужесточение идеологического контроля, появляются фильмы, создатели которых чутко констатируют глубину и остроту кризиса советской системы, а также существенные изменения общественного сознания» (Давиденко, 2004: 3-4).

Отсюда обращение авторов медиатекстов данного периода к вечным темам в искусстве - тема отцов и детей, человеческого возраста, нравственности, любви и ненависти, жизни и смерти, смысла жизни, поиск призвания, борьба нового и старого, прогрессивного и консервативного. Все эти темы актуальны и для советских игровых фильмов на студенческую тему.

Что касается советского кино эпохи Л. Брежнева о молодежи и для молодежи, то его уже не назовешь как прежде «целомудренным», т.к. кинообраз молодого советского поколения почти лишился того «героического флера» и «романтического ореола», который он приобрел в эпоху сталинизма и советской «оттепели», особенно это касается драматического реализма кинематографа позднего «застоя»: во многих медиатекстах «застойной» эпохи на студенческую тему четко ощущается драматический разрыв героев с социальной действительностью, внутренние и внешние социальные конфликты, несогласие со сложившимися общественныминормами и устоями, социальный протест, драма нереализованных внутренних возможностей...

\section{2. Материалы и методы исследования}

Материалом нашего исследования послужили советские игровые фильмы эпохи «застоя» (1969-1984) о студенчестве и вузе. Основные методы исследования включают герменевтический анализ аудиовизуальных медиатекстов, идеологический анализ, анализ стереотипов, идентификационный анализ, иконографический анализ, сюжетный анализ, анализ характеров персонажей, антропологический, ретроспективный и гендерный анализ.

Под герменевтическим анализом культурного медийного контекста мы понимаем «исследование процесса интерпретации медиатекста, культурных, исторических факторов, влияющих на точку зрения агентства/автора медиатекста и на точку зрения аудитории. Герменевтический анализ предполагает постижение медиатекста через сопоставление с культурной традицией и действительностью; проникновение в логику медиатекста; анализ медиатекста через сопоставление художественных образов в историко-культурном контексте (Федоров, 2014: 8).

Методологической основой нашего исследования послужили концепции и методы анализа медиатекстов, разработанные К. Бэзэлгэт (Бэзэлгэт, 1995), А. Силверблэтом (Silverblatt, 2001: 80-81) и У. Эко (Эко, 2005: 209), включая анализ таких ключевых понятий медиаобразования как «медийные агентства», «категории медиа/медиатекстов», 
«медийные технологии», «языки медиа», «медийные репрезентации» и «медийные аудитории».

Цель нашего исследования - выявить социокультурные тенденции в развитии общественного мнения и отношения к высшему образованию и студенчеству; раскрыть социально-политический, социально-экономический, культурно-исторический и духовнонравственный контексты создания медиатекстов данного исторического периода; определить роль и значимость темы вуза в культурологическом, киноведческом, антропологическом, гендерном и медиаобразовательном аспектах.

\section{3. Обсуждение}

Анализу советского кинематографа, включая эпоху «застоя» в СССР, посвящено достаточно большое число отечественных (Григорьева, 2007; Федоров, Левицкая, Горбаткова, 2017; Фомин, 2016; Щербенок, 2013; Зак, 2017 и др.) и зарубежных (Leckie, 2017; Prokhorov, Prokhorova, 2016; Rojavin, Harte, 2018; DeBlasio, 2014; Beumers, 2007; Kenez, 1992, et al.) научных статей и монографий киноведческого и культуроведческого характера. Отечественные исследования описывают специфику советского кино 1970-х, цивилизационный кризис в кино позднего «застоя» (Фомин, 2016; Щербенок, 2013; Зак, 2017), кинорепертуар и зрительские предпочтения в эпоху «застоя», вопросы кинопроката и кинофикации советской кинематографии, падение кинопосещаемости в 1970-х - начале 1980-х (Косинова, 2016). Значительная часть публикаций посвящена анализу медиаобразов школы, учителя, ученого, научной интеллигенции в советском, постсоветском и современном кино и масс-медиа (Аркус, 2010; Григорьева, 2007; Шипулина, 2010; Шаханская, 2017; Райхлина, Юрчик, 2016; Маченин, 2016; Солдаткина, 2016 и др.).

В центре внимания зарубежных историков, культурологов, искусствоведов и кинокритиков оказались такие вопросы как особенности советского кинематографа в послевоенный период; специфика женского образа в советском кино периода «застоя»; кинофильмы развлекательных жанров брежневской эпохи; жанровые модификации кино и телевидения позднего советского периода; анализ эпических фильмов, фильмов детективного и комедийного жанра; культура позднего социализма; идеологические и социальные конфликты социалистической эпохи и др. (Prokhorov \& Prokhorova, 2016; Beumers, 2007; Kenez, 1992, et al.).

Что же касается проблемы создания медиаобразов студента, преподавателя и вуза в зеркале советского/постсоветского кино, включая эпоху «застоя», то эта тема практически осталась без внимания в отечественной и зарубежной научной литературе, и, следовательно, нуждается в изучении и анализе. Некоторые примеры герменевтического анализа советских игровых фильмов о студентах, преподавателях и вузе можно встретить в нескольких работах российских исследователей (Федоров и др., 2017; Сальный, 2017; Михалева, 2017; Levitskaya et al., 2017).

\section{4. Результаты исследования}

Место действия, исторический, социокультурный, политический, идеологчческий контексты

Исторический контекст (доминирующие понятия: «медийные агентства», «категории медиа/медиатекстов», «медийные репрезентации» $u$ «медийные аудитории»)

Особенности исторического периода создания медиатекстов, условия рынка, которые способствовали замыслу, процессу создания медиатекстов, степень влияния событий того времени на медиатексты

Неоднозначный период, получивший название «застоя» в истории советского государства, до сих пор вызывает споры у современных отечественных и зарубежных историков. С одной стороны, это было время романических комсомольских строек, реформирования и индустриализации страны. Строились новые города, заводы, дворцы культуры, стадионы; открывались новые вузы, школы и больницы; продолжалось освоение космоса, развитие авиации, энергетики, фундаментальных и прикладных наук; улучшалось благосостояние советских граждан; усиливалась военная мощь страны. 
С другой стороны, в этот период наблюдался небывалый рост бюрократического аппарата; возобновились, ослабевшие в «оттепельные» времена, идеологическое давление и политическая пропаганда; постепенно снижались темпы экономического развития страны в силу роста, преимущественно, ресурсных секторов экономики; наблюдался упадок в аграрной политике; появился продовольственный и товарный дефицит, обострились международные отношения СССР с Западом. Вообще, в эту противоречивую эпоху большие начинания во многих случаях заканчивались большими провалами, и видимо, поэтому это время иногда очень часто называют «двадцатилетием упущенных возможностей», чьи определенные успехи стали залогом грядущих поражений.

Противоречивость эпохи «застоя» не могла не отразиться всоветском кинематографе: «Все то лучшее, здоровое, настоящее что, намечалось и стало прорастать в оттепельных фильмах, продолжало расти и развиваться дальше и в 1970-е годы. Только этот процесс протекал в другом - малопригодном для роста и развития климате. Не благодаря ему, а уже вопреки, наперекор. И, соответственно, общий пейзаж нашего кино стал выглядеть уже подругому» (Фомин, 2016).

Кинематограф в эпоху «застоя» передавал настроение своего переходного, контрастного и почти «смутного» времени. Так или иначе, кинокартины «позднесоветской цивилизации» отражали актуальные проблемы общества, кризисные социальные явления и конфликты, конечно, не выходя за рамки принятой идеологической доктрины.

Что касается фильмов о студенчестве и вузе, то медиатексты тех лет затрагивали такие проблемы как снижение статуса и престижа высшего образования в обществе, усиление бюрократизма и формализма в науке, социальный конформизм, конфликт поколений, проблема непонимания отцов и детей, нравственное состояние общества, тема безответственности и сиротства, потребительское отношение к жизни, одиночество и др.

Как знание реальных исторических событий конкретного периода помогает пониманию данных медиатекстов, примеры исторических ссылок в данных медиатекстах

Советский кинематограф эпохи «застоя» на студенческую тему отражал как положительные, так и отрицательные стороны окружающей действительности.

Например, относительно оптимистичные медиатексты о студенчестве, относящиеся к середине-концу 1970-х, содержат исторические ссылки на достижения и преимущества эпохи т.н. «развитого социализма»:

- развитие строительного сектора, повсеместное появление новостроек: «в каждом городе есть свои Черемушки...» («Это мы не проходили», 1975);

- рост научного потенциала страны; появление молодого поколения ученых, аспирантов, кандидатов наук, профессоров («Кузнечик», 1979; «Баламут», 1978);

- использование ЭВМ («Баламут», 1978; «Кафедра», 1982);

- рост реальных доходов населения, повышение благосостояния основной массы населения («Это мы не проходили», 1975; «Я буду ждать», 1979);

- снятие ограничения на ведение личного подсобного хозяйства в сельской местности («Баламут», 1978);

- гарантированное трудоустройство, низкий уровень безработицы, возможность карьерного роста, поощрения за отличную работу, например, премирование передовиков поездкой в «братские» прибалтийские республики («Моя Анфиса», 1979);

- улучшение ситуации в армии, милитаризация страны, «золотой век» для советских военных («Это мы не проходили», 1975); 1978).

- появление кооперативов, например, для улучшения жилищных условий («Баламут»,

С другой стороны, большая часть медиатекстов тех лет на студенческую тему содержит также исторические ссылки на негативные, «застойные» явления в политической, социальной и культурной жизни страны:

- неэффективная плановая экономика («Баламут», 1978); рост продовольственного и товарного дефицита, как следствие, - появление спекулянтов и фарцовщиков («Контрольная по специальности», 1981);

- убыточность совхозов и колхозов, неэффективное использование государственных средств, выделяемых на аграрный сектор; отсутствие необходимой социальной 
инфраструктуры в сельских районах; нехватка квалифицированных специалистов; общий упадок жизни в деревни, отсюда - массовый отток молодежи в город («Баламут», 1978; «Кузнечик», 1979);

- избыток специалистов с высшим образованием и острый недостаток квалифицированных рабочих кадров («Моя Анфиса», 1979);

- падение престижа высшего образования («Кафедра», 1982; «Моя Анфиса», 1979; «Контрольная по специальности», 1981).

Социокультурный, идеологический, мировоззренческий, религиозный контексты (доминирующие понятия: «медийные агентства», «категории медиа/медиатекстов», «медийные репрезентации» и «медийная аудитория»).

Идеология, мировоззрение авторов данных медиатекстов в социокультурном контексте; идеология, культура мира, изображенного в медиатекстах

Для эпохи «застоя» было характерно бессменное господство марксистко-ленинской идеологии и подавление всякого инакомыслия, которое выражалось в травле диссидентов. Курс на построение коммунизма, взятый руководством страны, привел к ужесточению государственной цензуры, кроме того развернулась борьба с теми, кто не желал мириться с установленными общественными правилами и открыто выражал свое несогласие или протест.

При этом «кинопроизводство оказалось под бо́льшим, чем в «оттепельные» времена, цензурным контролем, поэтому авторы большинства аудиовизуальных медиатекстов на школьно-вузовскую тему находились в этих строгих рамках, хотя с каждым годом школьновузовская тематика в советском кино шаг за шагом отвоевывала новый плацдармы «разрешенного» (Федоров и др., 2017).

В целом, авторы медиатекстов на студенческую тему создавали произведения, преимущественно, нейтральные в идеологическом плане, делая акцент на критическом осмыслении окружающей действительности, на освещении социальных конфликтов, на проблеме морально-нравственного и патриотического воспитании молодежи.

Мировоззрение людей «студенческого мира», изображенного в медиатекстах

Взгляды и убеждения героев «студенческого мира» связаны, прежде всего, с выбором личного или профессионального характера. Положительные персонажи медиатекстов стремятся найти смысл жизни, утвердится в профессии, самореализоваться, помочь нуждающимся в помощи, отстоять правду, встретить любовь и обрести счастье.

Антигерои медиатекстов о студенчестве либо лишены какой-либо принципиальной позиции и как бы «плывут по течению», либо, наоборот, стараются «взять от жизни» по максимуму - достичь материального благополучия или сделать карьеру любой ценой.

Отсюда ценностные ориентации молодежи в медиатекстах на студенческую темунапрямую зависят от жизненных приоритетов разных социальных типов молодого поколения: положительные персонажи ценят образование, дружбу, уважение, верность, любовь, семью. В то время как отрицательным героям свойственны вещизм, нравственная нечистоплотность, погоня за импортными товарами, беспринципный карьеризм.

Главные герои вузовской темы эпохи «застоя» - студенты (положительные персонажи) - целеустремленные, честные, порядочные, ответственные, независимые, самостоятельные, не боятся спорить с авторитетами, творческие натуры, способные к рефлексии и эмпатии, готовые на самопожертвование.

Отрицательные персонажи медиатекстов о студенчестве - «антипримеры» - молодые люди, юноши или девушки, страдают от эгоизма, инфантильности, беспринципности, трусости. Зачастую, такие персонажи - иждивенцы, добивающиеся успеха за счет других, «шагая по головам» и легкомысленно ломая чужие жизни.

В целом, медиаобразы студентов в фильмах эпохи «застоя» более или менее приближены к реалиям того времени, но главные положительные персонажи, призванные служить образцом для подражания, в большинстве случаев, - незаурядные личности, добившиеся успехов в учебе, спорте, работе, или вообще в жизни, часто конфликтующие или «невписывающиеся» в реальность общества массового конформизма.

3. Структура и приемы повествования в данных медиатекстах (доминирующие понятия: «категории медиа/медиатекстов», «медийные технологии», «языки медиа», «медийные репрезентации») 
Схематично структуру, сюжет, репрезентативность, этику, особенности жанровой модификации, иконографии, характеров персонажей можно представить следующим образом:

Место и время действия в медиатекстах. Время и место действия фильмов: СССР времен «застоя». Действие обычно происходит в Москве, иногда город не акцентируется в медиатексте.

Характерная для данных медиатекстов обстановка, предметы быта: приезжие студенты (в основном, из провинции) скромно живут в общежитии; студенты, находящиеся на иждивении родителей или супруга, живут в комфортных изолированных квартирах.

Жанровые модификации: драма, мелодрама, комедия.

Приемы изображения действительности и персонажей:

- положительные персонажи представлены достаточно стереотипно: положительные женские персонажи - независимые, самостоятельные, смелые, стремятся сохранить свою индивидуальность, ответственные, искренние, заинтересованы в получении образования и профессионального опыта;

- положительные мужские персонажи - добрые, отзывчивые, целеустремленные, защитники слабых, прямолинейные, настойчивые, решительные, преданы науке и/или работе; при этом в медиатекстах о студентах доминируют герои и героини, приехавшие из провинции «покорять» город;

- отрицательные женские персонажи встречаются нечасто, но если они есть, то - это антиподы положительных героинь - эгоистичные, бездушные, придерживающиеся потребительской или приспособленческой философии, часто живут на иждивении; вомежличностных отношениях они также меркантильны, придерживаются утилитарного подхода к образованию, науке и браку, хотя в финале фильма некоторые из них осознают свои ошибки и исправляются;

- отрицательные мужские персонажи встречаются чаще, чем женские: они либо ведут безнравственный образ жизни, либо находятся на попечении родителей, - это категория слабохарактерных, инфантильных и эгоистичныхперсонажей, хотя в конце фильма они тоже исправляются; иногда в медиатекстах эпизодически появляются весьма агрессивные хулиганы как некий деструктивный асоциальный элемент, но главные герои всегда успешно справляются с ними самостоятельно, либо с помощью вовремя подоспевшей советской милиции;

- тенденция изображать характеры главных героев в развитии: изначально позиционируемые как отрицательные характеры - девушки и юноши могут кардинально меняться к концу фильма: легкомысленные и безответственные героини становятся чрезвычайно серьезными, постепенно преодолевая жизненные трудности и анализируя свои поступки; в свою очередь, инфантильные и бесхарактерные юноши, будучи брошенными представительницами противоположного пола, неожиданно взрослеют, идут служить в армию и/или остепеняются в финале фильма;

- достаточно реалистичное изображение действительности (фактуры, интерьер, обстановка, предметы быта), за исключением ранних медиатекстов, предлагающих несколько идеализированный медиаобраз советской школы и вуза;

- в некоторых медиатекстах встречаются сцены, типичные для студенческого жанра: шумные товарищеские вечеринки и застолья с обязательным исполнением студенческой песни под гитару; поездки на уборку картошки в подшефном колхозе;

- прерывание в последовательности сюжетных событий - ретроспекция, мысленное обращение героев к прошлому, воспоминаниям для более глубокого изображения внутреннего мира персонажей («Кафедра», 1982; «Контрольная по специальности», 1981);

- внутренний диалог героя, рефлексия и самоанализ, сны для создания внутреннего портрета персонажа и раскрытия его душевного мира («Кузнечик», 1979; «Кафедра», 1982);

- закольцованные сюжеты в фильмах «Это мы не проходили» (1975), «Контрольная по специальности» (1981);

- использование лейтмотивов и повторяющихся кадров или сцен, значимых с точки зрения авторов медиатекстов в смысловом плане, в фильме «Я буду ждать» (1979) символичная сцена случайной встречи главных героев на лестнице, в фильме «Кафедра» 
(1982) - повторяющийся сон главного героя или кадр-пейзаж загородного дома, в котором они были счастливы с покойной супругой;

- дихотомический принцип построения сюжета медитекста, например, противопоставление «деревня-город» («Баламут», 1978; «Кузнечик», 1979), «прогрессивноеконсервативное» («Это мы не проходили», 1975), «материальные и нравственные ценности» («Контрольная по специальности», 1981), «бюрократизм и человечность» («Кафедра», 1982) и др.

- внимание к деталям-символам. Например, в фильме «Это мы не проходили» (1975) есть сразу несколько деталей. В финальном эпизоде учащийся школы, которого научил практикант-физик, ремонтирует перманентно неработающую кофеварку в местном кафе, которую зритель видит крупным планом в начале фильма. Другой пример - на первый взгляд несущественная деталь - модная сумочка практикантки, купленная ею в Лондоне и понравившаяся ее школьному куратору, символизирует связь поколений педагогов. В прощальной сцене фильма студентка-практикантка в знак благодарности дарит эту сумочку своей учительнице-наставнице. Еще один пример - портрет деда как символ ценности семьи и семейного воспитания, который учительница-практикантка советует родителям повесить на стену рядом с портретом известного архитектора, - в конце фильма мы видим на стене портрет дедушки, который сын - ученик практикантки завел в рамку и повесил на стену.

В фильме «Контрольная по специальности» (1981) одна из центральный деталей импортный магнитофон, за которым главная героиня изначально «охотилась» как за очередной новомодной игрушкой, но к концу фильма этот магнитофон уже приобретает положительную коннотацию и служит «дневником памяти» о героях Великой отечественной войны, в котором героиня хранит тяжелые воспоминания очевидцев.

- к концу «застойного» периода усиливается драматизм и психологизм в изображении героев медиатекстов, их характеров и судеб, их переживаний и внутренней борьбы с самим собой и с социумом, их сомнений и разочарований («Я буду ждать», 1979; «Контрольная по специальности», 1981; «Прощание за чертой», 1981; «Кафедра», 1982; «Моя маленькая жена», 1984).

Типология персонажей (черты характера, одежда, телосложение, лексика, мимика, жесты персонажей, присутствие или отсутствие стереотипной манеры репрезентации персонажей в даннъх медиатекстах):

- возраст персонажей: возраст студентов находится в пределах 18-25 лет; преподаватели могут быть разного возраста, в том числе - молодые доценты, научные работники и профессора;

- уровень образования: у студентов соответствует курсу обучения; преподаватели высококвалифицированные специалисты, научные работники; образование других персонажей может быть любого уровня;

- социальное положение, профессия: персонажи-студентки выбирают как типично «женские» гуманитарные профессии (педагог, филолог, художник, историк), так и профессии, ассоциируемые в то время исключительно с мужчинами (экономист, строитель, физик-математик), a персонажи-студенты также выбирают традиционно «мужские»профессии - естественно-научные или технические специальности (экономист, инженер, физик, химик) и нетехнические профессии (филолог, педагог, переводчик). Социальное положение других персонажей может быть любым;

- семейное положение персонажей: студенты обычно холосты; студентки не всегда стремятся выйти замуж за своих сверстников, некоторые выходят замуж за молодых преподавателей или военных, хотя неравные браки - это скорее исключение из правила; другие герои зачастую страдают от неразделенной или несчастной любви; становится возможным так называемый гражданский брак; нередки браки по расчету; семейное положение взрослых может быть разным, при этом встречаются матери-одиночки, разведенные женщины средних лет, женщины с неустроенной личной и семейной жизнью; мужчины преклонного возраста - обычно вдовцы.

- внешний вид, одежда, телосложение персонажей, черты их характеров, лексика: внешний вид персонажей-студентов представлен довольно дифференцированно: девушки современные, одеваются по моде того времени, уверенные в себе, активные, смелые, с 
характером; мужские персонажи одеты соответственно их возрасту, статусу и реалиям тех лет. Иногда в кадре мелькают иностранные студенты.

Кадр из фильма «Это мы не проходили» (1975), представленный ниже, отражает внешний вид, одежду, телосложение персонажей-студентов тех лет.

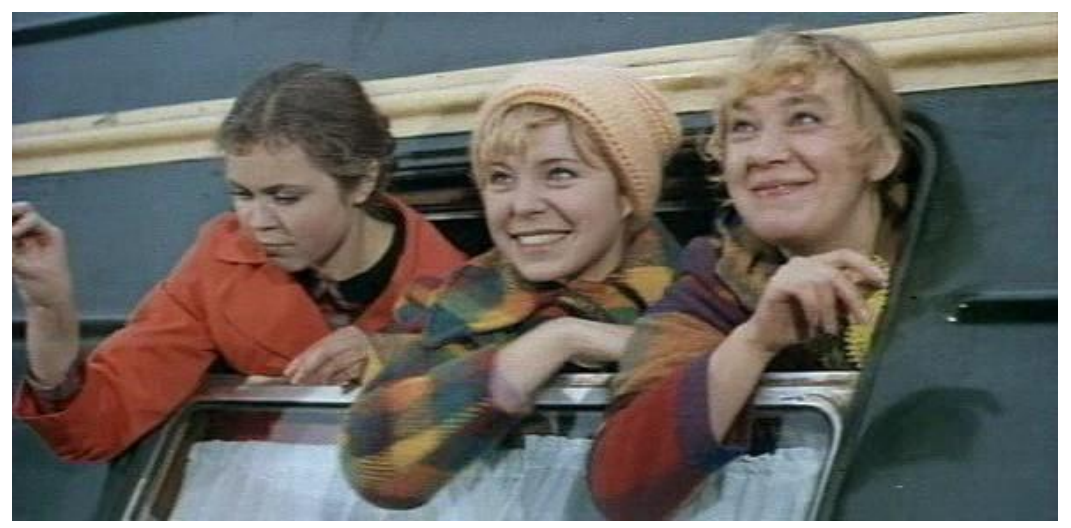

Рис. 1. Кадр из фильма «Это мы не проходили» (1975)

Существенное изменение в жизни персонажей медиатекстов, возникшая у персонажей проблема и ее решение:

- сюжетный вариант 1: абитуриенты поступают в вуз или уже учатся в вузе, затем у них возникают проблемы разного характера во время учебы - не могут сдать сессию, попадают на практику, несерьезно относятся к учебе и др.; в финале фильма студенты успешно справляются с проблемами - приобретают первый профессиональный опыт, упорно работают и успешно сдают сессию, становятся серьезнее и меняют свое отношение к учебе, будущей профессии и жизни вообще благодаря влиянию взрослого поколения («Это мы не проходили», 1975; «Баламут», 1978; «Контрольная по специальности», 1981);

- сюжетный вариант 2: студенты вступают в официальный или гражданский брак, либо собираются обзавестись семьей; их семейные или романтические отношения терпят крах по разным причинам - разочарование в браке по расчету, неопытность, разочарование в выбранном спутнике жизни, измена; решением проблемы становится разрыв, иногда весьма болезненный для главных героев, но в некоторых случаях авторы медиатекстов оставляют зрителям надежду на возможность счастливого воссоединения героев в результате перевоспитания «отрицательного» персонажа («Кузнечик», 1979; «Моя Анфиса», 1979; «Я буду ждать», 1979; «С тех пор как мы вместе», 1982);

- сюжетный вариант 3: пожилой уважаемый профессор, заведующий кафедрой в вузе, отходит от научной работы после смерти супруги и через некоторое время тоже умирает, на его место назначают нового заведующего, которого педагогический коллектив кафедры не принимает; осознав свою неспособность руководить людьми, новый заведующий берет самоотвод («Кафедра», 1982).

Сюжетный анализ советских игровых фильмов эпохи «застоя» на студенческую тему очерчивает круг центральных проблем, отраженных ванализируемых медиатекстах:

- выбор будущей профессии и жизненного пути, поиск своего призвания и места в жизни;

- первый опыт профессиональной деятельности и первые разочарования;

- проблемы межличностных отношений (дружба, безответная любовь, измена, предательство);

- опыт первых романтических / семейных отношений;

- проблемы молодой семьи, неравные браки, браки по расчету;

- конфликт поколений (дети и родители, студенты и преподаватели, старшие коллеги и молодые кадры);

- проблемы нравственного выбора между истиной и ложью, любовью и богатством; готовность к самопожертвованию; 
- острые социальные проблемы (сиротство, неполные семьи, матери-одиночки, потребительское отношение к жизни, лицемерие и бездуховность, ханжество, бюрократизм, алкоголизм, хулиганство и др.).

Кадры из фильмов эпохи «застоя» на студенческую тему отражают некоторые из вышеперечисленных отрицательных явлений той эпохи - пьянство, хулиганство, сиротство...

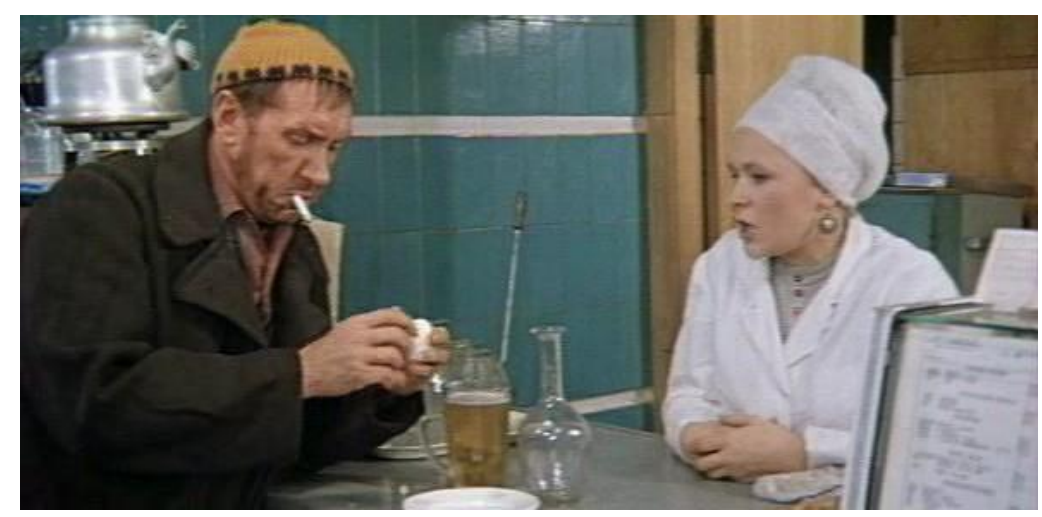

Рис. 2. Кадр из фильма «Это мы не проходили» (1975)

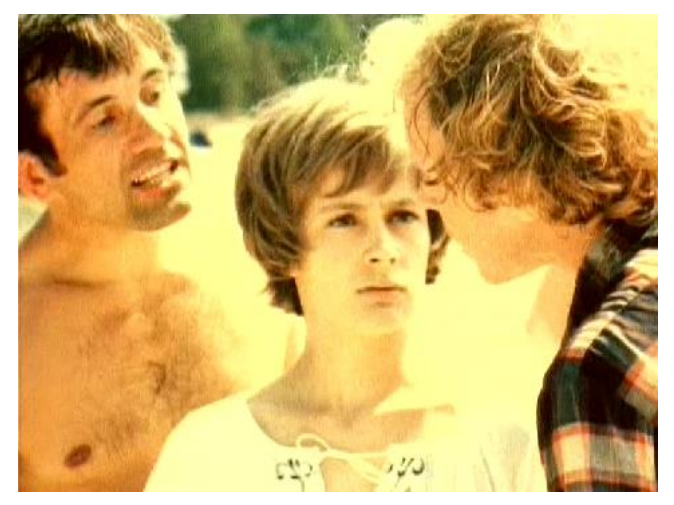

Рис. 3. Кадр из фильма «Кузнечик» (1979)

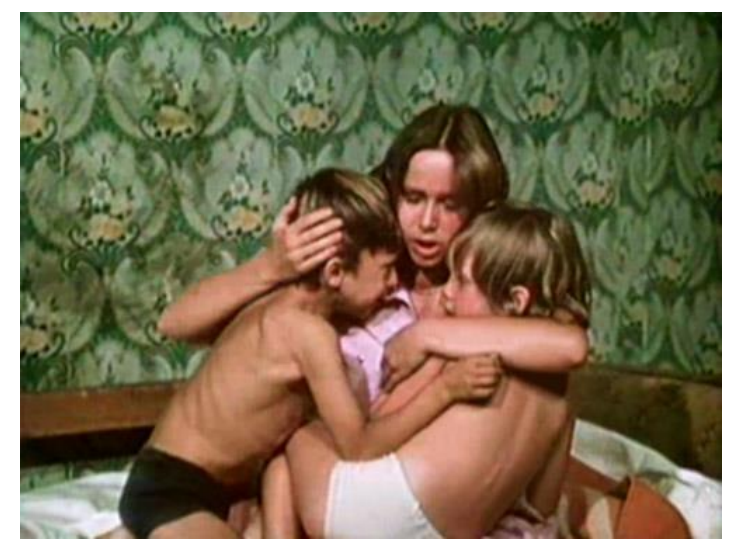

Рис. 4. Кадр из фильма «Контрольная по специальности» (1981)

Несмотря на снижение престижа высшего образования в эпоху «застоя» по разным причинам, в частности, из-за «уравниловки» в оплате квалифицированного и неквалифицированного труда, судя по советским фильмам на студенческую тему, у абитуриентов была достаточно высокая мотивация поступить в вуз, особенно у молодых 
людей из провинции: «Прощай Чеботаревка и клуб наш облезлый!» - говорит главная героиня фильма «Кузнечик» (1979), уезжая «покорять» столицу. Для многих юношей и девушек вуз той эпохи ассоциировался с новой жизнью, возможностью изменить свою судьбу, повысить социальный статус, добиться чего-то важного в жизни...

С другой стороны, в некоторых медиатекстах подчеркивается, что мотивы у современной молодежи, поступающих в вузы, могут быть далеко не самые благородные. Например, юноши не́хотя учатся ввузе, опасаясь как бы их не взяли служить в армию («Моя Анфиса», 1979); студентки-провинциалки забрасывают учебу как только выходят замуж, причем часто по расчету («Кузнечик», 1979), многие студенты достаточно формально относятся к учебе или жульничают на экзаменах («Баламут», 1978; «Контрольная по специальности», 1981).

При этом медиаобраз студента «застойного» периода в значительной степени отличается от медиаобраза, например, эпохи «оттепели». Особенно это касается женских образов: они стали более реалистичными, - это уже «не рафинированные интеллигентки» (эпитет из фильма «Кафедра», 1982), они смело влюбляются в преподавателей («Баламут», 1978), не боятся трудностей жизни («Это мы не проходили», 1975), делают аборты («Баламут», 1978), страдают от неразделенной любви («Кафедра», 1982), вступают в гражданский брак, прыгают с парашютом («Моя Анфиса», 1979), берут на себя ответственность за жизнь и воспитание чужих детей («Контрольная по специальности», 1981).

Типология медиаобразов юношей-студентов тоже расширилась по сравнению с фильмами эпохи «оттепели» на студенческую тему: в кадре появились социальные типы негероического и неромантического склада - «маменькины сынки», иждивенцы, циники.

Медиаобраз советского учителя/преподавателя в медиатекстах о студенчестве и вузе также претерпел некоторую трансформацию, и он уже не ограничивается только двумя основными социальными типами советских учителей: учитель-«наставник», обладающий профессиональным и моральным авторитетом, и учитель-«активист», наследник «человека в футляре» (Солдаткина, 2016: 273).

Во-первых, персонажи-преподаватели в анализируемых медиатекстах о вузе эпохи «застоя» - это не только великовозрастные светилы науки, но и молодые ученые, аспиранты или профессора. «Молодая кровь» позволяет авторам медиатекстов несколько «разбавить» традиционный геронтократический медиаобраз преподавателя советского вуза, доминировавший в медиатекстах предшествующих эпох. Наряду с «преподавателямититанами» - учеными с мировым именем, на экране появляются молодые преподавателиэнтузиасты, рядовые преподаватели-предметники или практики, преподаватели-педанты, безразличные преподаватели, или преподаватели, страдающие от синдрома «профессионального выгорания»...

Во-вторых, авторы как бы разрешают зрителям «заглянуть» в личное пространство учителей/преподавателей и познакомиться с их семейной ситуацией, их внутренними переживаниями, тревогами и мыслями, отсюда - медиаобразы преподавателей также становятся более реалистичными и «полнокровными». Например, мы узнаем, что внешне вполне успешные учителя и педагоги, - принципиальные и искренне преданные своей профессии люди, зачастую страдают от одиночества, разочарований и «маленьких трагедий» их невидимой личной жизни. Причем это в равной степени касается как женских, так и мужских персонажей («Это мы не проходили», 1975; «Кафедра», 1982; «Баламут», 1978).

Постепенно меняются и стили профессионально-педагогического общения преподавателей со студентами в медиатекстах на студенческую тему: ощущается переход от авторитарного к демократическому стилю. «Сближение» преподавателя и ученика, видимо, обусловлено желанием авторов медиатекстов подчеркнуть новые тенденции в советском образовании: «советские аудиовизуальные тексты 1969-1985 годов на тему школы и вуза, по мысли властей, должны были поддерживать основные линии тогдашней государственной политики в образовательной и социокультурной сферах, то есть показать, что советская система образования, воспитания и культуры при сохранении общих идеологических ориентиров: бережно относится к внутреннему миру школьника и ориентируется на формирование «всесторонне развитой личности»; отношения педагогов и учащихся 
продолжают оставаться демократичными, в какой-то степени творческими;в школе и вузе есть проблемные зоны» (Федоров, Левицкая, Горбаткова, 2017).

Кадры из фильмов эпохи «застоя» на студенческую тему, представленные ниже, отражают медиаобразы советских преподавателей вузов тех лет.

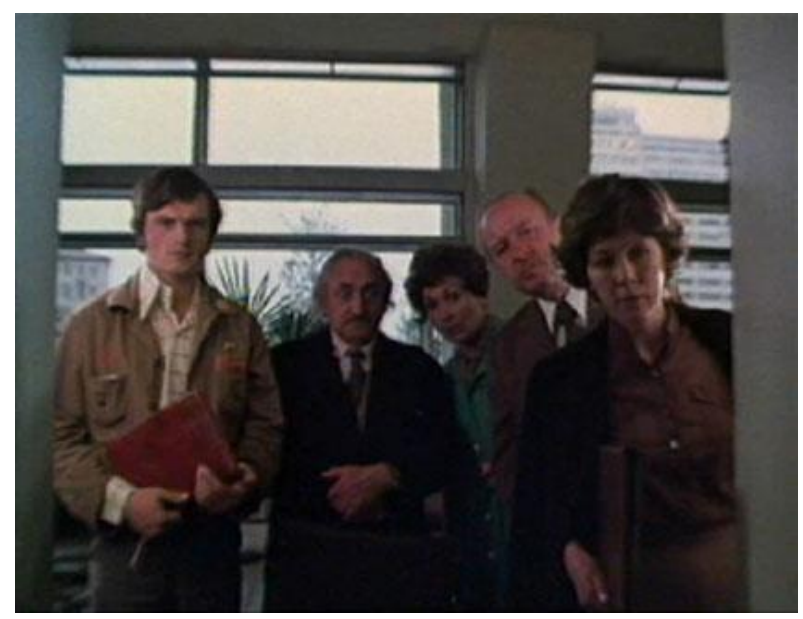

Рис. 5. Кадр из фильма «Баламут» (1978)
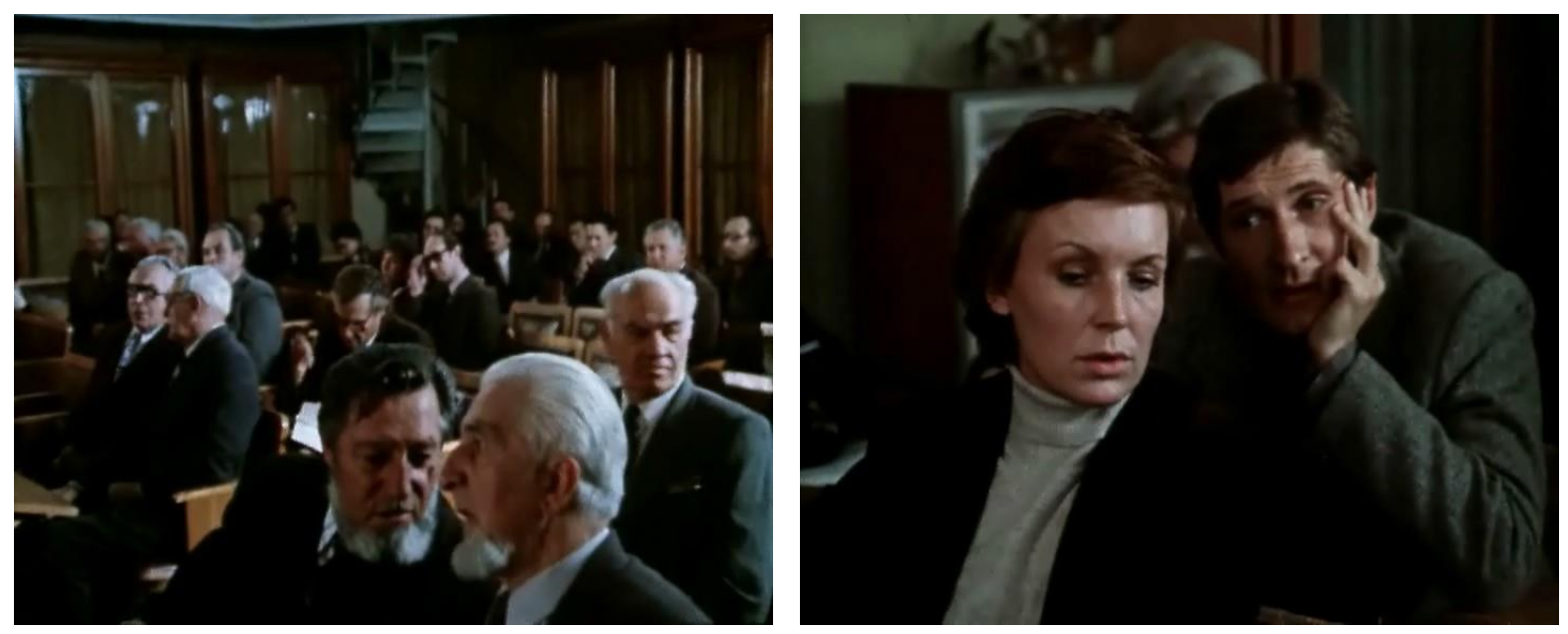

Рис. 6. Кадры из фильма «Кафедра» (1982)

\section{5. Выводы}

В ходе герменевтического анализа советских игровых фильмов эпохи «застоя» на студенческую тему мы пришли к выводам, что советский кинематограф эпохи «застоя», формально остававшийся в рамках коммунистической идеологии:

- создавал преимущественно нейтральные в идеологическом плане медиатексты, делая акцент на критическом осмыслении окружающей действительности, освещении социальных конфликтов, проблеме морально-нравственного и патриотического воспитании молодежи, повышении общей культуры молодого поколения;

- обращался к вечным темам в искусстве (любовь и ненависть, жизнь и смерть, конфликт поколений и др.);

- отражал как положительные (достижения в строительном, жилищном, аграрном, военном, космическом секторах экономики; низкая безработица и др.), так и отрицательные (сиротство, бюрократизм, социальный кризис, потребительское отношение к жизни, алкоголизм и др.) стороны в социально-политической и культурной жизни советского народа;

- продолжал использовать стереотипные ролевые и гендерные характеристики персонажей; 
- расширил проблематику и сюжетный диапазон медиатекстов о студенчестве;

- более реалистично представлял медиаобразы советского преподавателя и студента по сравнению с кинематографом эпохи «оттепели»;

- разнообразил спектр социальных типов медиаобразов студентов и преподавателей вуза;

- расширил диапазон художественных приемов изображения героев и окружающей действительности; и судеб.

- усилил драматизм и психологизм в изображении героев медиатекстов, их характеров

\section{6. Благодарности}

Статья написана в рамках исследования при финансовой поддержке гранта Российского научного фонда (РНФ). Проект № 17-18-01001 «Школа и вуз в зеркале советских, российских и западных аудиовизуальных медиатекстов», выполняемый в Ростовском государственном экономическом университете.

\section{Литература}

Аркус, 2010 - Аркус Л.Ю. Приключения белой вороны: эволюция «школьного фильма» в советском кино // Сеанс. 2010. 2 июня. http://seance.ru/blog/whitecrow/

Бэзэлгэт, 1995 - Бэзэлгэт К. Ключевые аспекты медиаобразования. М.: Изд-во Ассоциации деятелей кинообразования, 1995. $51 \mathrm{c}$.

Власов, 1997 - Власов М.П. Советское кино семидесятых - первой половины восьмидесятьх годов. Учебное пособие. М.: ВГИК, 1997, 180 с.

Григорьева, 2007 - Григоръева О. Образ учителя в советском кино: от «Весенней» оттепели до «Большой перемены» // Визуальная антропология: новые взгляды на социальную реальность / Под ред. Е.Р. Ярской-Смирновой, П. В. Романова, В. Л. Круткина. Саратов: Научная книга, 2007. С. 223-239.

Давиденко, 2004 - Давиденко Д.А. Человек и действительность в отечественном кинематографе 7о- $x$ годов. Автореф. ... канд. искусствоведения. Москва: ВГИК, 2004. 24 с.

Зак, 2017 - Зак M.E. Русское кино 70-х годов // Русское кино. https://www.russkoekino. ru/books/ruskino/ruskino-0007.shtml

Зудина, 2011 - Зудина А.А. Наука и образ ученого в советском кино (1928-1986 годы) // Общественные науки и современность. 2011. № 5. С. 167-176.

Косинова, 2016 - Косинова М.И. Кинорепертуар и зрительские предпочтения в эпоху «Застоя» // Вестник университета. 2016. № 6. С. 255-259.

Маченин, 2016 - Маченин А.А. Собирательный образ школьного учителя в отражении теле/кино/интернет медиапространства // Медиаобразование. 2016. № 3. С. 23-48.

Михалева, 2017 - Михалева Г.В. Герменевтический анализ медиатекста на примере советского игрового фильма на студенческую тему эпохи сталинизма // Журнал Министерства народного просвещения. 2017. № 1. С. 25-37.

Назарова, 2006 - Назарова И.Б. Типология преподавателей высшей школы // Социологические исследования. 2006. №11. С. 115-119.

Райхлина, Юрчик, 2016 - Райхлина Е.Л., Юрчик Н.Н. Образ учителя в русском кинематографе // Молодой ученый. 2016. № 13. С. 60-62.

Сальный, 2017 - Сальный P.В. Герменевтический анализ советских игровых фильмов о студентах эпохи перестройки (1986-1991) // Журнал Министерства народного просвещения. 2017. № 1. С. 38-46.

Солдаткина, 2016 - Солдаткина Я.В. Медиаобраз учителя в современных средствах массовой информации: основные направления и факторы трансформации // Bопросы теории и практики журналистики. 2016. Т. 5. № 2. С. 261-277.

Теплинский, 2006 - Теплинский O.B. Научная интеллигенция в советском кинематографе: Основные тенденции репрезентации. Автореф. ...канд. ист. наук. Краснодар, 2006. 24 c.

Федоров, 2014 - Федоров А.В. Словарь терминов по медиаобразованию, медиапедагогике, медиаграмотности, медиакомпетентности. М.: МОО «Информация для всех», 2014. 64 c. 
Федоров и др., 2017 - Федоров А.В., Левицкая А.А., Горбаткова О.И. Направления, цели, задачи, авторские концепции аудиовизуальных медийных трактовок темы школы и вуза в советском кино эпохи «застоя» (1969-1985) // Медиаобразование. 2017. № 3. http://psyfactor.org/kinoprop/fedorov44.htm

Федоров и др., 2017а - Федоров А.В., Левицкая А.А., Горбаткова О.И. Школа и вуз в зеркале аудиовизуальных медиатекстов: основные подходы к проблеме исследования // Медиаобразование. 2017. № 2. С. 187-206.

Фомин, 2016 - Фомин В.И. Советское кино 1966-1980 гг.: расцвет в эпоху застоя? Музей кино: интервью. http://www.museikino.ru/media_center/sovetskoe-kino-1966-1980-gg-rastsvetv-epokhu-zastoya/

Шаханская, 2017 - Шаханская А.Ю. Сравнительный анализ эволюции образа педагога в советских и российских плакатах и профессиональных фотографиях // Журнал Министерства народного просвещения. 2017. № 1. С. 47-61.

Шипулина, 2010 - Шипулина Н.Б. Образ учителя в советском и современном российском кинематографе // Известия ВГПУ. 2010. № 8 (52). С. 4-16.

Щербенок, 2013 - Щербенок А. Цивилизационный кризис в кино позднего застоя // НЛО. 2013, № 123. http://magazines.russ.ru/nlo/2013/123/8sh-pr.html

Эко, 2005 - Эко У. Роль читателя. Исследования по семиотике текста. СПб: Симпозиум, 2005. $502 \mathrm{c}$.

Bahun, Haynes, 2014 - Bahun, S. \& Haynes, J. (eds.) (2014). Cinema, State Socialism and Society in the Soviet Union and Eastern Europe, 1917-1989: Re-Visions (BASEES/Routledge Series on Russian and East European Studies), 1st Edition. Abingdon: Routledge, 234 p.

Beumers, 2007 - Beumers, B. (2007). The Cinema of Russia and the Former Soviet Union. London: Wallflower Press, 288 p.

De Blasio, 2014 - DeBlasio, A. (2014). The New-Year film as a genre of post-war Russian cinema.Studies in Russian and Soviet Cinema. Vol. 2, Iss. 1. Taylor \& Francis Online. http://www.tandfonline.com/doi/abs/10.1386/srsc.2.1.43_1

Kenez, 1992 - Kenez, P. (1992). Cinema and Soviet Society, 1917-1953. Cambridge: Cambridge University Press, 281 p.

Leckie, 2017 - Leckie, J. (2017). Stagnation and Soviet Films: An Unlikely Romance. Prospect Magazine: Pop and Culture. http://www.prospektmag.com/2017/o8/stagnation-sovietfilms-an-unlikely-romance/

Levitskaya et al., 2017 - Levitskaya A., Seliverstova L., Mamadaliev A. Gender Analysis of the Development of School and University Theme in Soviet and Russian Audiovisual Media Texts // European Journal of Contemporary Education, 2017, 6(4): 723-731.

Prokhorov, Prokhorova, 2016 - Prokhorov, A. \& Prokhorova, E. (2016). Film and Television Genres of the Late Soviet Era.New York: Bloomsbury Publishing, 240 p.

Rojavin, Harte, 2018 - Rojavin, M., Harte, T. (eds.) (2018). Women in Soviet Film.The Thaw and Post-Thaw Periods.Abingdon: Routledge, $214 \mathrm{p}$.

Shlapentokh, 1993 - Shlapentokh, D. \& V. (1993). Soviet Cinematography 1918-1991: Ideological Conflict and Social Reality. N.Y.: Aldine de Gruyter, 278 p.

Silverblatt, 2001 - Silverblatt, A. (2001). Media Literacy. Westport, Connecticut. London: Praeger, $449 \mathrm{p}$.

\section{References}

Arcus, 2010 - Arcus, L. (2010). Adventures of the white crow: evolution of a "school film" in the Soviet cinema. Séance. June, 2. http://seance.ru/blog/whitecrow/

Bazalgette, 1995 - Bazalgette, C. (1995). Key Aspects of Media Education. Moscow: Edition of Association for Film Education, $51 \mathrm{p}$.

Beumers, 2007 - Beumers, B. (2007). The Cinema of Russia and the Former Soviet Union. London: Wallflower Press, 288 p.

Davidenko, 2004 - Davidenko, D. (2004). Man and reality in Russian cinematograph of the 1970s. Ph.D. thesis abstract. Moscow: VGIK, $24 \mathrm{p}$.

DeBlasio, 2014 - DeBlasio, A. (2014). The New-Year film as a genre of post-war Russian cinema. Studies in Russian and Soviet Cinema. Vol. 2, Iss. 1. Taylor \& Francis Online. http://www.tandfonline.com/doi/abs/10.1386/srsc.2.1.43_1 
Eco,2005 - Eco, U. (2005). The role of the reader.Studies on the semiotics of the text. St. Petersburg: Symposium, 2005. 502 p.

Fedorov, 2014 - Fedorov, A. (2014). Media education dictionary: media education, media literacy, media studies, media competence. Moscow: ICO “Information for All". $64 \mathrm{p}$.

Fedorov et al., 2017 - Fedorov, A., Levitskaya, A., Gorbatkova, O. (2017). School and university in the mirror of audiovisual media texts: basic approaches to the research problem. Media Education. № 2, 187-206.

Fedorov et al., 2017a - Fedorov, A., Levitskaya, A., Gorbatkova, O. (2017). Directions, goals, tasks, author's concepts of audiovisual media interpretations of the topic of the school and university in the Soviet cinema of the "stagnation" era (1969-1985). Media Education. 2017. № 3. http://psyfactor.org/kinoprop/fedorov44.htm

Fomin, 2016 - Fomin, V. (2016). Soviet cinema of the 1966-1980s: renaissance in the epoch of stagnation? Film Museum: interview. http://www.museikino.ru/media_center/sovetskoe-kino1966-1980-gg-rastsvet-v-epokhu-zastoya/

Grigorieva, 2007 - Grigorieva, O. (2007). The image of the teacher in the Soviet cinema: from the "Spring" thaw till "Big break". Visual anthropology: new views on social reality. Saratov: Scientific book, pp. 223-239.

Kenez, 1992 - Kenez, P. (1992). Cinema and Soviet Society, 1917-1953. Cambridge: Cambridge University Press, 281 p.

Kosinova, 2016 - Kosinova, $M$. (2016). Repertoire of cinemas and audience preferences in the era of "stagnation". University Bulletin, № 6, 255-259.

Leckie, 2017 - Leckie, J. (2017). Stagnation and Soviet Films: An Unlikely Romance. Prospect Magazine: Pop and Culture. http://www.prospektmag.com/2017/o8/stagnation-sovietfilms-an-unlikely-romance/

Levitskaya et al., 2017 - Levitskaya A., Seliverstova L., Mamadaliev A. Gender Analysis of the Development of School and University Theme in Soviet and Russian Audiovisual Media Texts. European Journal of Contemporary Education, 2017, 6(4): 723-731.

Machenin, 2016 - Machenin, A. (2016). Image of a school teacher in the reflection of TV / film / Internet media space. Media Education. № 3, 23-48.

Mikhaleva, 2017 - Mikhaleva, G. (2017). Hermeneutic analysis of the media text (example: Soviet cinema of the Stalinism time about university students). People's Education Ministry Journal. № 1, 25-37.

Mitina, 2015 - Mitina, T. (2015). Image of a teacher in the Soviet cinema at the beginning of the $20^{\text {th }}$ century. Siberian Scientific Bulletin. № 2, 124-128.

Nazarova, 2006 - Nazarova, I. (2006). Typology of university teachers. Sociological studies. № 11, pp. 115-119.

Prokhorov \& Prokhorova, 2016 - Prokhorov, A., Prokhorova, E. (2016). Film and Television Genres of the Late Soviet Era.New York: Bloomsbury Publishing, 240 p.

Raikhilina\&Yurchik, 2016 - Raikhilina, E., Yurchik, N. (2016). Teacher's image in the Russian cinematograph. Young scientist. № 3, 60-62.

Rojavin \& Harte, 2018 - Rojavin, M., Harte, T. (eds.) (2018). Women in Soviet Film.The

Thaw and Post-Thaw Periods. Abingdon: Routledge, 214 p.

Salny, 2017 - Salny, $R$. (2017). Hermeneutic analysis of Soviet feature films about students (1986-1991). People’s Education Ministry Journal. № 1, 38-46.

Shahanskaya, 2017 - Shahanskaya, A. (2017). Comparative analysis of the evolution of the image of the teacher in the Soviet and Russian posters and professional photos. People's Education Ministry Journal. № 1, 47-61.

Shcherbenok, 2013 - Shcherbenok, A. (2013). Civilizational crisis in the cinema of the late stagnation era. NLO. № 123. http://magazines.russ.ru/nlo/2013/123/8sh-pr.html

Shipulina, 2010 - Shipulina, N. (2010). The image of a teacher in the Soviet and modern Russian cinema. News of VGPU, № 8 (52), 4-16.

Shlapentokh, 1993 - Shlapentokh, D. and V. (1993). Soviet Cinematography 1918-1991: Ideological Conflict and Social Reality. N.Y.: Aldine de Gruyter, 278 p.

Silverblatt, 2001 - Silverblatt, A. (2001). Media Literacy. Westport, Connecticut. London: Praeger, $449 \mathrm{p}$. 
Soldatkina, 2016 - Soldatkina, Y. (2016). The media image of teacher in contemporary media: the main themes and factors of its transformation. Theoretical and Practical Issues of Journalism. V. 5. № 2, 261-277.

Teplinsky, 2006 - Teplinsky, O. (2006). Scientific intelligentsia in the Soviet cinematograph: basic tendencies of representation. Ph.D. thesis abstract. Krasnodar: Krasnodar State University of Culture and Arts, 24 p.

Vlasov, 1997 - Vlasov, M. (1997). Soviet cinema of the 1970s - the first half of the 189os. Moscow: VGIK, $180 \mathrm{p}$.

Zak, 2017 - Zak, M. (2017). Russian cinema of the 1970s. Russian cinema. https://www.russkoekino.ru/books/ruskino/ruskino-0007.shtml

Zudina, 2011 - Zudina, A. (2011). A Science and an Image of the Scientist in the Soviet Cinema (1928-1986). Socials siences and modern times. № 5, 167-176.

\title{
УДК 37
}

\section{Герменевтический анализ советских игровых фильмов эпохи «застоя» (1969-1984 гг.) на студенческую тему}

\author{
Г.В. Михалева ${ }^{\text {a, * }}$ \\ a Ростовский государственный экономический университет, Российская Федерация
}

Аннотация. В настоящей статье приведены результаты герменевтического анализа советских игровых фильмов эпохи «застоя» (1969-1984) на студенческую тему путем сопоставления данных медиатекстов с культурно-исторической традицией и действительностью данного временного периода. Цель нашего исследования - путем анализа охарактеризовать и раскрыть культурно-исторический контекст, определить роль и значимость темы вуза в зеркале советского кино эпохи «застоя» в социокультурном, культурологическом, киноведческом, антропологическом, гендерном и медиаобразовательном аспектах. Автор статьи приходит к выводам, что советский кинематограф эпохи «застоя», формально остававшийся в рамках коммунистической идеологии: 1) создавал преимущественно нейтральные в идеологическом плане медиатексты, делая акцент на критическом осмыслении окружающей действительности, освещении острых социальных конфликтов, проблеме морально-нравственного и патриотического воспитания молодежи, повышении общей культуры молодого поколения; 2) обращался к вечным темам в искусстве; 3) отражал как положительные аспекты и достижения советского государства, так и отрицательные стороны в социальнополитической и культурной жизни; 4) продолжал использовать стереотипные ролевые и гендерные характеристики персонажей в медиатекстах; 5) расширил проблематику и сюжетный диапазон медиатекстов о студенчестве и вузе; 6) более реалистично представлял медиаобразы советского преподавателя и студента по сравнению с кинематографом эпохи «оттепели»; 7) разнообразил социальную типологию медиаобразов студентов и преподавателей вуза; 8) расширил диапазон художественных приемов изображения персонажей и окружающей действительности; 9) усилил драматизм и психологизм в изображении героев медиатекстов, их характеров и судеб.

ключевые слова: герменевтический анализ, медиатекст, фильм, персонажи, СССР, медиаграмотность, эпоха «застоя», советский кинематограф, вуз, студенты, преподаватели.

\footnotetext{
${ }^{*}$ Корреспондирующий автор

Адреса электронной почты: gmikhaleva@list.ru (Г.В. Михалева)
} 


\section{Приложение}

\section{Фильмография советских игровых фильмов эпохи «застоя» (1969-1984) на студенческую тему}

Это мы не проходили. СССР, 1975. Режиссер Илья Фрэз. Сценаристы: Илья Фрэз, Михаил Львовский. Актеры: Наталья Рычагова, Борис Токарев, Андрей Ростоцкий, Татьяна Канаева, Ирина Калиновская, Антонина Максимова, Татьяна Пельтцер, Нина Зоткина, Вера Васильева и др. Драма.

Баламут. СССР, 1978. Режиссер Владимир Роговой. Сценарист Сергей Бодров (ст.). Актеры: Вадим Андреев, Наталья Казначеева, Николай Денисов, Владимир Шихов, Валентина Клягина и др. Комедия.

Кузнечик. СССР, 1979. Режиссер Борис Григорьев. Сценарист Феликс Миронер. Актеры: Людмила Нильская, Николай Иванов, Людмила Аринина, Анатолий Ромашин, Марина Левтова, Вячеслав Баранов и др. Драма.

Моя Анфиса. СССР, 1979.РежиссерЭдуард Гаврилов. Сергей Бодров. Актеры:Марина Левтова, Леонид Каюров, Юрий Каюров, Нина Меньшикова, Николай Парфёнов, Любовь Соколова, Марина Яковлева, Ольга Токарева, Юрий Чернов и др.

Я буду ждать. СССР, 1979. Режиссер Виктор Живолуб. Сценарист Анатолий Степанов. Актеры: Николай Ерёменко (мл.), Анна Твеленёва, Ирина Шевчук, Константин Степанков, Рита Гладунко, Юрий Каморный и др. Мелодрама.

Контрольная по специальности. СССР, 1981. Режиссер Борис Шадурский. Сценаристы: Игорь Болгарин, Марта Пятигорская. Актеры: Евгения Симонова, Руфина Нифонтова, Инна Макарова, Антон Табаков, Тамара Акулова и др. Мелодрама.

Кафедра. СССР, 1982. Режиссер Иван Киасашвили. Сценаристы: Ирина Грекова, Семён Лунгин, Марк Розовский (автор одноименной повести - И. Грекова). Актеры: Андрей Попов, Светлана Кузьмина, Ростислав Янковский, Галина Макарова, Елена Степанова, Игорь Ясулович, Елена Антоненко, Александр Кайдановский, Виктор Сергачёв и др. Драма.

С тех пор, как мы вместе. СССР, 1982. Режиссер Владимир Григорьев. Сценарист Святослав Тараховский. Актеры: Светлана Смирнова, Андрис Лиелайс, Антонина Шуранова и др. Мелодрама.

Моя маленькая жена. СССР, 1984. Режиссер Раймундас Банионис. Сценарист Римантас Шавялис. Актеры: Элеонора Коризнайте, Саулюс Баландис, Ингеборга Дапкунайте и др. Мелодрама. 